\title{
Is there an Olympic Gold Medal Rush in the Stock Market?
}

\begin{abstract}
Investor sentiment and attention are often linked to the same non-economic events making it difficult to understand why and how asset prices are affected. We disentangle these two potential drivers of investment behaviour by analysing a new dataset of medals for major participating countries and sponsor firms over four Summer Olympic Games. Our results show that trading volume and volatility are substantially reduced following Olympic success although returns appear to be largely unaffected. Analysis of data from on-line search volumes and surveys measuring investor sentiment, also suggest that the market impact of the Olympics is linked to changes in attention.
\end{abstract}

Keywords: Attention, Sentiment, Olympic Games, Stock Market JEL Classification: G02, G14 
Oh enjoying the thrill of the chase is fine. Craving the distraction of the game, I sympathize entirely.

But sentiment, sentiment is a chemical defect found in the losing side.

Sherlock Holmes, A Scandal in Belgravia (BBC, 2012)

\section{Introduction}

The central idea in this paper is that major non-economic events, such as soccer matches, holidays or good weather, cannot be used as an indirect proxy of sentiment, as they also affect the attention of investors. Information and behavioural biases, such as those caused by sentiment, are reflected in asset prices only to the extent that investors pay attention to market-related activities. In this sense, attention is a prerequisite for shifts in the mood of investors, a necessary but not sufficient condition for financial impact. If investors are distracted by the loss of the team they support, for example, the decline in their mood may not find its way into the stock market. What we may observe, however, is a reduction in market activity. Our research sheds doubt on the unbiasness of non-economic events as proxies of investor behaviour and justifies a deeper investigation

of the joint importance of sentiment and attention. $\quad{ }^{1}$ To this end, we analyse a new dataset of medal results over four Summer Olympic Games for eight major economies (US, UK, France, Australia, Netherlands, Germany, South Korea and Japan) and five multinational sponsoring firms (Coca Cola, McDonald's, Panasonic, Visa, Samsung). We ask if the stock market impact of the Games and gold medals is due to a shift in the mood of investors or to a distraction of their attention. Results indicate that there is no significant statistical association between medal performance and abnormal returns over the next trading day. However, trading volumes and volatility are significantly lower during Olympic Games and are further reduced as a function of the gold medals won over 
the previous day. For example, for each gold medal won by the U.S., the trading volume in the S\&P 500 firms is almost 3\% less on the following day. For Germany and South Korea, this decrease is even higher at $6.7 \%$ and $7.3 \%$, respectively. These statistical regularities can be exploited through simple volatility trading strategies in the U.S. which produce positive profits in excess of those from a passive approach. Our results are consistent with recent theories of investor attention, but cannot be explained on the basis of investor sentiment. We also show that Olympic Games have an impact on a more direct measure of investor attention based on online search volumes, but not on direct survey-based measures of investor sentiment. We conclude that in the case of Olympic Games, it is investor attention rather than mood that is driving the effect on the stock market.

Our study follows De Long et al. (1990) and other researchers arguing that irrational investors may also exist in the market that are influenced by psychological and behavioural factors. We concentrate on two of these factors, investor sentiment and attention, for three main reasons. First, although a considerable amount of research is devoted on showing the significant empirical effects of these factors on financial markets, they are treated separately in the literature (examples for sentiment include Saunders Jr 1993; Barberis et al. 1998; for attention see Barber and Odean 2008; Peng and Xiong 2006). Since attention and sentiment may have a similar impact on investors, a joint investigation of their importance is justified. For example, sentiment is often proxied on the basis of exogenous events, such as sports outcomes, which are considered to have a significant impact on the mood of investors (see Edmans et al. 2007). However, investor attention may also be significantly affected during these events which raises concerns about their unbiasness as sentiment proxies. Although not studied in this paper, our results 
suggest more generally that the use of continuous variables for capturing investor sentiment, such as temperature or cloudiness, potentially suffer from the same problems. Our research produces interesting new evidence about the validity of competing hypotheses and theoretical models of investor sentiment and attention. This allows us to better understand how economic agents operate within markets and if their motivation is more behavioural or rational. Second, our study is one of the few in the literature which examines the impact of sentiment and attention at both the market and firm level. In addition to increasing the robustness of the results, this is important since it is possible that effects are diluted at the aggregate level due to noise or heterogeneity between firms (Baker and Wurgler, 2007). Finally, correctly measuring the effects of sentiment and attention has practical implications for the design of superior event-driven investment strategies (Kaplanski and Levy, 2010a; Coakley, Dotsis, Liu and Zhai, 2014).

Our previously unexplored dataset of Olympic Game medals offers advantages over existing data drawn from other sports, such as soccer matches and the Super Bowl, used by other studies. This is because the Olympic Games are more likely to affect significantly the behaviour of investors since they constitute the most globalised and important sports event in terms of national and corporate impact. This means that we can adopt different units of analysis which include developed and developing participating countries along with multinational sponsoring firms. For example, compared to the 2010 FIFA World Cup, which is another important sports event of comparable importance (Edmans et al., 2007;

Ehrmann and Jansen, 2012), the 2012 Summer Olympics involved 204 countries (compared to 32 which qualified in the FIFA), 26 sports (1, soccer), 219.4 million TV viewers in the U.S. (94.5 million), \$13.6 billion in organising costs (\$3.6 billion), \$5.6 
billion worth of advertising ( $\$ 36$ million) and $\$ 100$ million for each of 11 partners worth of partner sponsorship deals (between $\$ 24$ to $\$ 44$ million for each one of 6 partners every year from 2007 to 2010) (data drawn from IOC and FIFA websites and various newspaper articles). For the 2008 Olympics, it is estimated that up to 4.7 billion viewers (or $70 \%$ of the world population) watched some part of the coverage (Press release, Nielsen Media Research, 8 September 2008). In the U.S. alone, the London Olympics constitute the most-watched television event on NBC with an average of 31.1 million viewers and unprecedented traffic, consumption and engagement on digital platforms (NBC Press Release, 14 August 2012). The economic, social and political importance of the Olympics means that evidence about their effects on the stock market is highly relevant for organisers, policy makers and advisors. Our findings concerning the impact of the Olympics on individual sponsor firms are particularly useful for managers in these firms but also for investors and market makers.

\section{Literature}

Since the seminal work of De Long et al. (1990), several papers argue that the behaviour of some investors deviates from the norm of full rationality which underlies the standard model of market efficiency. Whilst this literature takes several different directions (for a review see Barberis and Thaler, 2002; Shiller, 2003; Baker and Wurgler, 2007), we concentrate here on the work related to sentiment and attention. Although these two effects are treated separately, we show how they are related and focus on their joint investigation. A brief overview of each literature follows. 
The interest in the role of sentiment, feelings, mood and emotions in business and finance stems from the seminal work of Kahneman and Tversky (1979). Research in this area builds on evidence from experimental psychology and economics and studies how investors are affected in the evaluation of information, risk, gains and future prospects. Investor sentiment is estimated in empirical studies using a variety of approaches (Baker and Wurgler, 2007; Bathia and Bredin, 2013). Direct measures involve posing questions to investors through surveys, such as those undertaken by the American Association of Individual Investors, Investors Intelligence, etc. General surveys of consumer confidence, such as the University of Michigan Consumer Sentiment Index, are also sometimes used as they are known to have a close relationship to investor sentiment. Indirect proxies typically assume that sentiment is influenced through the psychological mechanism of “mood misattribution” (Ross, 1977). Simply put, sports success or sunny weather influence the mood of some investors and make them more optimistic. In turn, this makes them more willing to enter into long positions, which leads to higher returns in the shortrun. The causal link between the actual events and the mood of investors is based on evidence from psychology which demonstrates, for example, that certain events influence the general mood in the population (Kavetsos and Szymanski, 2010; Dawson etal., 2014).

As noted by Edmans et al. (2007), the two principal approaches for indirectly measuring investor sentiment are based on continuous variables and a single event respectively. The continuous variables used include: weather conditions (Saunders Jr, 1993; Hirshleifer and Shumway, 2003; Symeonidis et al., 2010; Schmittmann et al., 2014), lunar cycles (Yuan et al., 2006) and market variables (e.g., performance, types of 

trading, derivatives positions; see Brown and Cliff 2004). Event based studies use, for example, aviation disasters (Kaplanski and Levy, 2010b); changes to and from daylight saving (Kamstra et al., 2003) and holidays (Frieder and Subrahmanyam, 2004). Finally, another proxy for sentiment that is popular recently is based on the textual analysis of news (Tetlock, 2007; Loughran and McDonald, 2011; Ferris et al., 2013). Overall, the empirical evidence has shown that sentiment is associated with stock returns in an asymmetric manner according to which poor mood has a stronger effect (see, forexample Edmans et al., 2007; Kaplanski and Levy, 2010a). Beyond the first moment, there is some controversy in the literature concerning the link between investor sentiment and market volatility. A comprehensive study by Symeonidis, Daskalakis, and Markellos (2010) demonstrates that good mood, as proxied by weather and environmental variables, is associated with increased volatility.

Within the sentiment literature, our paper is related to an influential study by Edmans et al. (2007) that proposes sports results as an indirect investor mood proxy.

The authors argue that losses in international games of soccer, cricket, rugby and basketball induce a negative mood which in turn leads to lower returns in the stock market over the next day. In line with the prospect theory of Kahneman and Tversky (1979), the effect of match results is asymmetric since wins are found not to affect returns. Further evidence of the economic significance of these results is presented by Kaplanski and Levy (2010a). At the firm level, Chang et al. (2012) show that National Football League (NFL) game losses lead to lower next-day returns for locally headquartered NASDAQ firms. The importance of sports sentiment for the stock market is also analysed in Super Bowl (US) by Krueger and Kennedy (1990), in soccer (UK) by Ashton et al. (2003), in horse-racing 
(Australia) by Worthington (2007), in rugby by Boyle and Walter (2003) and in cricket (India) by Mishra and Smyth (2010). Finally, Bernile and Lyandres (2011) and Palomino et al. (2009), show that investor sentiment is important for stock prices of publicly traded soccer clubs.

The exploration of attention in finance also stems from studies in psychology which deal with the limitations to rationality (Simon, 1957; Kahneman, 1973). Part of this literature concentrates on how limited attention influences judgments and memory and leads to behavioural biases such as the halo effect, the illusion of truth and magical thinking (Yantis, 1998). Another strand emphasises more the nature of attention as a scarce resource and studies how this is allocated in a positive or normative manner between all the different decisions and activities that investors are facing (Veldkamp, 2011). The work of Sims (2003) studies the limited attention of an economic agent as an information processing constraint and its implications in dynamic consumption choice. The arguments for the impact of attention in finance often draw from the vast "dual-task interference" literature in psychology which shows convincingly that humans cannot effectively complete two or more tasks simultaneously (Pashler, 1994). As Ehrmann and Jansen (2012) point out, attention may be inversely related to the complexity (Cohen and Frazzini, 2008), the quantity (Hirshleifer and Shumway, 2003), the time horizon (DellaVigna and Pollet, 2009) and non-saliency of the available information (Huberman and Regev, 2001). Moreover, attention may differ across time, countries and firms (Barber and Odean, 2008). Some of the empirical implications that are attributed to attention include the post-earnings announcement drift, the accrual anomaly, the profit anomaly (Hirshleifer et al., 2011), asset mispricing (Brown, 2014), firm valuation (Cumming and Dai, 2011) and the reaction 
to stale news (Gilbert et al., 2012). In terms of empirical measurement, investor attention is proxied using variables such as distance to weekends (DellaVigna and Pollet, 2009), holidays (Jacobs and Weber, 2011), Google search volumes (Da et al., 2011), market maker activity (Corwin and Coughenour, 2008) and saliency of events (Barber and Odean, 2008).

Although there is growing empirical evidence about the importance of attention, few relevant theoretical frameworks exist. DellaVigna and Pollet (2009) develop a model of the response of stock prices to earnings announcements in which a proportion of investors is assumed to be distracted. The share of inattentive inventors amplifies the delayed response of prices to news about earnings. Peng and Xiong (2006) model a representative investor and solve for her optimal attention allocation in the presence of overconfidence. In this model attention is assumed to be fixed and is shown to endogenously lead to category-learning behaviour where investors tend to process more market rather than firmrelated information. An interesting aspect of this model is that it allows for inattention but also for sentiment in the form of overconfidence. However, this overconfidence is assumed to affect only the cognitive capacity to process information rather than mood. Andrei and Hasler (2015) study the joint importance of endogenously determined investor attention and uncertainty and show how these drive risk premia and volatility. Increased attention in their model means that market-related news are informative and volatility increases while uncertainty is reduced. Although variance and risk premia of stock returns increase quadratically with attention and uncertainty, attention is a more powerful driver of volatility. Attention to news varies across time according to changes in the state of the economy but is under the direct control of the investor. Schmidt (2013) develops a 
model of rational attention according to which investors allocate more weight to market news over firm specific news when attention is scarce. The author proxies attention scarcity on the basis of the intensity of sports-related search activity on Google. When attention is distracted by sports events, trading volumes are smaller, while volatility and synchronicity become higher. A novelty of the model against others in the rational attention literature (e.g., Sims, 2003; Peng and Xiong, 2006; Kacperczyk et al., 2014) is that attention can be allocated between leisure time, such as following sports, and, learning news which allows obtaining more precise signals for investment decisions. Within the attention literature, our study is related to Ehrmann and Jansen (2012) and Schmidt (2013) who use sports events to capture inattention amongst investors. Ehrmann and Jansen (2012) analyse high frequency data to show that market level trading volumes and co-movements with global stock returns are reduced during soccer matches and goals. In our paper, rather than looking at what happens during sports events, we focus on the subsequent short term effect that these events have on stock market activity.

Our study of data related to Olympic Games is not novel in the literature although our perspective is original. The economic, social and political significance of the Olympic Games has motivated researchers to examine their impact empirically for hosting countries (see the review by Kavetsos and Szymanski 2010) and sponsoring firms (Farrell and Frame, 1997; Miyazaki and Morgan, 2001; Hanke and Kirchler, 2013) but the evidence has been largely inconclusive. Several studies suggest that the Olympics may have "well-being", "feel-good" or "happiness" benefits stemming from attending events, volunteering, national pride, etc. For example, Kavetsos and Szymanski (2010) use a variety of major sporting events, including Olympics, to demonstrate significant feel- 
good effects in the short term for hosting countries. However, they also find that the association between national athletic success and happiness is statistically insignificant in their sample (further support to these results is given by Oxford Economics 2012). As emphasised by Kavetsos and Szymanski (2010) and Dawson et al. (2014), exploring the impact of Olympic Games on happiness is important since this is assumed as given by politicians and it is adopted as a primary policy objective. For example, one of the two strategic priorities that the Blair Government set out in the bidding for, and hosting, the London Olympics in 2012 was "a sustainable improvement in success in international competition, particularly in the sports which matter most to the public, primarily because

of the 'feel-good factor' associated with winning” (DCMS/ Strategy Unit, 2002, p.12). Outside the Olympics, Palomino et al. (2009) are one of the few studies that examine sports sentiment and investor attention. They use a sample of listed British soccer teams and study the variation in stock prices conditional to match outcomes and betting odds. The evidence suggests that investor sentiment has an impact on prices while the effect of attention is less clear. Drawing more general conclusions from these results is limited by the sample used since it includes only 16 firms from one country over three years. Moreover, these firms are all from the sports industry where shareholders are likely to be also fans and are more prone to sentimental effects.

\section{Hypothesis Development}

Our hypotheses involve the effect of positive outcomes from major sports events on investor sentiment, attention and stock market activity. These are motivated by the literature reviewed in the previous section. First, we examine the direction of this effect on stock market activity, as measured by trading volume and volatility, respectively. Sports 
success is proxied in our study by the number of Olympic medals won by a particular country

or sponsoring firm.

\section{Hypothesis I: Sports success leads to a decrease in stock market activity}

The existing literature on the effect of sports events does not examine this particular hypothesis and focuses on interpretations that involve investor sentiment alone. We study the strength and nature of this effect by considering the possibility of both investor sentiment and attention. On the one hand, existing theories and evidence from an investor sentiment perspective suggest that sports success should have a weak or insignificant positive effect on stock market returns (see Edmans et al., 2007). However, it is not clear in the literature what the effect of sentiment is on trading volume and volatility (see Symeonidis et al., 2010). On the other hand, the literature on investor attention predicts a positive relationship between the level of investor attention and market activity (e.g., see Andrei and Hasler (2015) for a relevant theoretical justification; for relevant empirical evidence see Ehrmann and Jansen, 2012; Vlastakis and Markellos, 2012). In our particular empirical setting, there is evidence which implies that the general population and workers are significantly distracted. For example, in August 2008, when Olympics took place, the time spent watching TV by all UK viewers was 3,898 minutes (2.09 hours per day), compared to 3,418 minutes (1.83 hours per day) in 2007 (Ofcom, 2012), an increase in viewership by $14 \%$. The same report notes survey evidence on the media intentions of UK consumers for the London 2012 Games which suggests that around one in four people in full time employment reported a priori that they are likely 
to watch or listen the events coverage at work (for evidence on other sports see also

Lozano, 2011; Hagn and Maennig, 2008).

In order to shed further light on the driving forces behind the market activity effect of sports events, we first examine how success in Olympic Games affects direct measures of investor sentiment under the following hypothesis.

\section{Hypothesis II: Sports success has a positive effect on investor sentiment}

In our empirical analysis, we use five proxies for sentiment. First, the Michigan Consumer Sentiment Index which is based on a monthly telephone survey of a minimum of 500 interviewees. It is calculated from the balance between favourable vs unfavourable responses on 50 core questions concerning views on the financial situation of the interviewees and the economy in general (for a detailed description see Lemmon and Portniaguina, 2006). Second, the Wurgler sentiment index which is based on six sentiment proxies which involve information with respect to closed-end fund discounts, equity share turnover, first day returns on IPOs, IPO volumes, equity share in new issues and the dividend premium (see Baker and Wurgler, 2007). Third, the Dow Jones ESI indicator which is based on the relative sentiment of text references to the US economy on the basis of 15 major daily newspapers (see Vazsonyi, 2010). Fourth, the IPSOS Global Primary Consumer Sentiment Index (PCSI) which measures consumer sentiment is based on the composite response of consumers to 11 questions across 24 countries. The questions are about current and future economic conditions, intentions and expectations, consumer confidence, job security and investments in the future. Finally, the American Association of Individual Investors Investor 
Sentiment Survey (AAII) indicator which measures sentiment though aweekly survey of individual investors with respect to their bullish, bearish, or neutral on the stock market over the next six months (see Brown and Cliff, 2004).

In addition to the effect of sentiment, we also examine the hypothesis that Olympic success may distract investors.

Hypothesis III: Sports success has a negative effect on investor attention

Here we use a direct measure of attention, the Search Volume Index (SVI), which is based on the intensity of investment related queries on Google (see also Da et al., 2011; Vlastakis and Markellos, 2012).

\section{Empirical Analysis}

\subsection{Sample description}

Our sample covers four Summer Olympic Games (2000, 2004, 2008, 2012) and eight countries: United States of America, United Kingdom, France, Australia, Netherlands, Germany, Japan and South Korea (a full list of the variables and acronyms used in this study is given in Table 1). These countries are Olympic "superpowers" and consistently rank at the top positions in terms of the medal winning index over the sample period. It is important to study several countries since there is evidence that both sentiment (Jones et al., 2012) and attention (Ehrmann and Jansen, 2012) may have different effects across cultures. The U.S. leads in terms of Olympic performance by winning $11.08 \%$ of total medals over the four games studied. The performance of these countries is stable over 
time as indicated by the fact that their total medal count proportion per year ranges between $34.76 \%$ and $43.05 \%$ (for the US it is $10.45 \%, 10.92 \%, 11.48 \%$ and $11.45 \%$ for 2000, 2004, 2008 and 2012 respectively). It is known from previous research that Olympic success at the country level is linked to economic performance (Bernard and Busse, 2004). So, it comes as no surprise that the countries in our sample are significant economic powers with stock markets that have an important role in the global environment. All countries, except for South Korea, can be clearly classified as developed (e.g., see 2014 MSCI market classification). South Korea is usually classified as an emerging market (e.g., in MSCI and Dow Jones Global Index), but sometimes appears as a developed market (e.g., in the Dow Jones Global Total Stock Market and S\&P Global BMI indices). Our sample also includes five firms which have been major (also known as worldwide) sponsors for the Summer Olympic Games throughout the period of study:

Coca Cola, Visa, McDonald's, Panasonic and Samsung. The three first are listed on the New York Stock Exchange (NYSE) while Panasonic and Samsung are listed on the Tokyo Stock Exchange and Korea Exchange, respectively. All firms are multinational corporations with a global consumer and investment base and a combined capitalisation of over half a trillion dollars on 1 August, 2012.

For each country in our sample, we hand collect from a variety of online sources data on gold, silver and bronze medals won over the sample period. ${ }^{2}$ Our sample includes all of the 3,729 medals across 35 different sports won by the eight countries studied between 2000 and 2012. In addition to the overall results, we also study a subsample of medals from the five most popular sports according to the definition given by the International Olympic Committee (IOC). This definition is based on the number of visits to the pages of the 
IOC website for different sports from January 2004 to 11 February 2005 (see IOC Report to the $117^{\text {th }}$ IOC Session from 24 May 2005).

Datastream is used to draw financial data. For each country we collect daily stock prices and trading volumes related to a major basket index: S\&P500 (US), FTSE (UK), CAC (FRA), ASX (AUS), AEX (NLD), DAX (GER), KOSPI (KOR) and NIKKEI (JPN). As in Edmans et al. (2007), we use total returns (assuming that dividends are reinvested) in local currency since we are primarily interested in the impact for domestic investors. The MSCI World Total Return (Net) Index is used to approximate the stock market return at a global level. We also gather daily observations on the following implied volatility indices: VIX (US), VFTSE (UK), VCAC (FRA), SPAVIX (AUS), VAEX (NLD), VDAX (GER), VKOSPI (KOR), VXJ (JPN). Daily measures of realised volatility on a simple 5- minute estimator are drawn from the Oxford-Man Institute website. Stock price and volume data for sponsor firms are collected for the five stocks under study.

Descriptive statistics of the logarithmic returns for the stock indices and firms under study are summarized in Table 2. As is typical with daily returns, all series are leptokurtotic with excess kurtosis and in most cases negative skewness. The average return over the whole sample is lower than that over the period of the Olympic Games for all countries and firms, except one (SAM). However, none of these differences are statistically significant on the basis of a two-tailed $t$-test. This is a first indication that Olympic euphoria is not transmitted to the stock market. The most (least) volatile market in the sample is South Korea (Australia) with an annualised daily standard deviation of $26.7 \%$ (16.9\%). The descriptive statistics indicate clearly that unconditional standard deviation is much lower over the Olympic period for all but one country (South Korea) and three of the firms (KO, 
MCD and SAM). For example, the standard deviation of S\&P 500 daily returns is $18.3 \%$

lower during the Olympic Games. A two-sided chi-squared test confirms that these differences are highly significant and not due to sample error. A further investigation of the effect on stock market activity indicates that unconditional measures of implied volatility, realised volatility and trading volume tend to be significantly lower than average during the Olympic Games compared to the complete sample. For instance, the average implied and historical volatility is more than $30 \%$ lower for the countries studied. Average trading volume is over $20 \%(16 \%)$ less for countries (firms). These results suggest that whilst returns seem to be unaffected during Olympics, market activity is significantly less for all markets and all but one of the sponsor firms (SAM). However, since market activity may be significantly influenced by market conditions and calendar effects, a further investigation in a regression framework is undertaken in the following section.

The final step in our preliminary analysis is to test for stationarity. Results from Augmented Dickey-Fuller (ADF) and Phillips-Perron tests, available upon request, suggest that both our logarithmic return and volume series do not contain a unit root.

\subsection{Hypothesis I: Sports success leads to a decrease in stock market activity}

We follow the two-stage event study approach of Edmans et al. (2007) in investigating the effect of Olympic medals on returns, volatility and trading volume. The last two are used as proxies for market activity. We analyse returns in order to compare results with those obtained from other sports in the literature. In the first stage of our event study, we treat the series in order to remove the effect of the market and calendar regularities:

$$
R_{i t}=p_{i O}+p_{i 1} M_{t}+p_{i 2} R_{i t-1}+p_{i 3} M_{t-1}+p_{i 4} M_{t+1}+p_{i 5} M N_{t}+y_{i 1} D_{1 t}+c_{i t}
$$




$$
\begin{aligned}
& \mathrm{TV}_{i t}=p_{i 0}+p_{i 5} \mathrm{MON}_{t}+\sum^{12}{ }_{j=1} \mathrm{y}_{\mathrm{ij}} \mathrm{D}_{\mathrm{jt}}+\mathrm{c}_{\mathrm{it}} \\
& \mathrm{VOL}_{\mathrm{it}}=\mathrm{p}_{\mathrm{iO}}+\mathrm{p}_{\mathrm{i} 5} \mathrm{MON}_{\mathrm{t}}+\sum^{12}{ }_{\mathrm{j}=1} \mathrm{y}_{\mathrm{ij}} \mathrm{D}_{\mathrm{jt}}+\mathrm{c}_{\mathrm{it}}
\end{aligned}
$$

Where $\mathrm{R}_{\mathrm{it}}, \mathrm{TV}_{\mathrm{it}}$ and VOLit is the return, volume and volatility for country or firm $\mathrm{i}$ at time $t$, respectivelly. $\mathrm{MON}_{\mathrm{t}}$ is a calendar dummy variables for Monday. $\mathrm{D}_{\mathrm{jt}}$, with $j=1,2, \ldots, 12$, is a calendar dummy variable for months with January taking the first value. Mit is the market portfolio index which is proxied using a MSCI global and national index return in the case of countries and firms, respectively. The specification of the models follows Edmans et al. (2007) and includes leading and lagging values in order to account for autocorrelations and microstructures.

In the second stage we regress the estimated residuals $\hat{c}_{i t}$ from the above regressions against gold medals won by each country over the previous day (if gold medals are won when the market is closed, these medals are aggregated in order to capture a compound effect on attention):

$$
\hat{c}_{\mathrm{it}}=\mathrm{b}_{\mathrm{i} 1} \mathrm{GOLD}_{\mathrm{it}-1}+\mathrm{b}_{\mathrm{i} 2} \mathrm{GAMES}_{\mathrm{t}}+\mathrm{u}_{\mathrm{it}}
$$

GOLD $_{\mathrm{it}-1}$ in the case of countries is the number of gold medals won by country i over the previous trading day. When analysing sponsor firm series, GOLD $\mathrm{it}-1$ is the number of medals at a national level in the country where the firm is listed. We also use an alternative measure which includes the total number for the eight countries analysed. The two measures allows us to investigate effects for sponsor firms at a local and global level, respectively. We also include a dummy $\left(\mathrm{GAMES}_{\mathrm{t}}\right)$ in order to capture any systematic 
effects that may occur over the whole Olympic period. This will capture a possible general positive spirit or higher level of distraction during the days Olympic Games.

In addition to gold medals, we estimate the regressions using silver, bronze and total medals (sum of gold, silver and bronze) along with medals won in the five most popular sports (including gold, silver, bronze and total medals). Following Kaplanski and Levy (2010a), in addition to looking at the effect of medals for each one of the eight countries and five firms, we also look at the collective effect that the total number of medals for all countries has on the U.S. stock market. These different ways of measuring sports success and impact add robustness to our analysis and shed more light on our hypotheses.

\subsubsection{Effect of Olympic Success on Stock Returns}

In line with the previous literature, we find that success in terms of Olympic medals is not significantly related to stock returns at the market and sponsor firm level (results available upon request). The nature of the sports we are studying and our dataset means that only success can be directly measured for most sports. For example, for soccer, which involves two teams it may be possible to identify a winner and loser during the final but for the marathon the silver medal may not be considered a failure. Since betting odds data are not readily available for Olympic Games, we attempt an analysis of the unexpected element in the medals using the average number of medals per country for each sport over the sample period as an estimate of the expected result. Specifically, we first calculate for each sport the likelihood (p1) for each country of winning a medal as the percentage of medals the country won divided by the total number of medals awarded. Then for each Olympic event, we calculate for each sport the actual number of medals 
won by each country (p2). The difference between $\mathrm{p} 1$ and $\mathrm{p} 2$ gives a proxy for the surprise element. This will be positive (negative) if the country wins a larger (smaller) proportion of total medals than expected for each sport compared to what it won overall over the complete sample of four Games. Rather than using the total number of medals, this calculation can be done also on the basis of gold medals only. For example, in Archery the U.S. won in 2000 (over the four games) a total of two medals (three medals over four games), none of which was gold. Therefore, the surprise is zero for gold medals. The total number of medals in Archery is twelve for each Olympic game so the overall proportion of medals won by the US over the sample of four Olympics is $6.25 \%(3 \div(4$ $\times 12))$. The actual proportion of medals won in 2000 is $16.67 \%(2 \div 12)$ so there is a positive surprise for that event which is $10.42 \%(16.67 \%-6.25 \%)$ for total medals. This allows us to measure positive and negative surprises and assess any asymmetry in the impact of sports performance. We repeat the regression analysis using surprise-weighted medal results. The results once again suggest that Olympic performance is not linked to stock returns. Conclusions are comparable even if we allow for an asymmetric effect of positive and negative surprises in the test regression (4). Our measure of surprise has the limitation of not being able to capture large investments by a country in sport which shift the expectations and chances of achieving better results. Under such circumstances, our deviations from the historical norm will appear incorrectly as positive surprises. However, as we consider a large number of sports and country investments tend to be more focused, the effects are probably not very strong. A much more accurate measure of surprise could be based on betting odds. Unfortunately, such an analysis was not possible as the necessary data was not available at the time this study was undertaken. 


\subsubsection{Effect of Olympic Success on Trading Volume}

The results in Table 3 confirm our descriptive analysis and indicate an inverse relationship between the number of gold medals and trading volume over the next day for all countries and firms, except for Japan. In other words, the results confirm the effect of attention on trading volume. In all cases, except UK, Australia, Japan, Coca Cola and Panasonic, the relationship is statistically significant at the $10 \%$ level. Comparable results are obtained for the alternative measures of success. As expected, gold medals appear to have a more significant impact on volume compared to silver medals with the average coefficient $b_{1}$ in regression (4) being on average higher in magnitude for the countries studied (-0.0507 for gold compared to -0.0454 and -0.0345 for silver and bronze, respectively).

\subsubsection{Effect of Olympic Success on Volatility}

Similar conclusions are reached from the analysis of realised and implied volatility indices shown in Table 4. The relationship is correctly signed in all regressions but one(Australia) and is statistically significant at the $10 \%$ level in most cases. Results are highly significant for the U.S., Germany and Netherlands. The magnitude of the coefficient for each individual country is small, implying a marginal effect. However, the collective impact of all countries on the U.S. stock market is significant and substantial in magnitude, with each additional gold medal decreasing realised volatility by almost $20 \%$.

Following Edmans et al. (2007), we also test our hypothesis by assuming that the conditional variance $\mathrm{o}_{\mathrm{it}}^{2}$ of residuals $\mathrm{c}_{\mathrm{it}}$ from equation (1) follows the threshold $\operatorname{GARCH}(1,1)$ model of Glosten et al. ( 1993): 


$$
\begin{aligned}
& \mathrm{oit}^{2}=\mathrm{m}_{\mathrm{i}}+{ }^{*}{ }_{\mathrm{i} 1} \mathrm{c}^{2}{ }_{\mathrm{it}-1}+{ }^{*}{ }_{\mathrm{i} 2} \mathrm{O}_{\mathrm{it}-1}^{2}+{ }^{*} \mathrm{ic}_{\mathrm{it}-1}^{2} \mathrm{I}_{\mathrm{it}-1}+\mathrm{d}_{\mathrm{i}} \mathrm{GOLD}_{\mathrm{it}} \\
& \text { where } \mathrm{I}_{\mathrm{it}-1}=1 \text { if } \mathrm{c}_{\mathrm{it}-1}<0 \text { and } 0 \text { otherwise }
\end{aligned}
$$

Where $m_{i}$ is the unconditional variance. The results in Table 5 allow similar conclusions to those obtained from the analysis of implied and realized volatility. For all firms and countries studied, a negative relationship is found between gold medals and historical volatility over the next day and it is statistically significant in most cases (including US, UK, FRA, JPN, TUS and four of the companies studied).

The final step in the analysis is to examine if the statistical regularities uncovered are economically significant. In line with the literature (Kaplanski and Levy, 2010a), we investigate the U.S. since this is by far the largest market in our sample. Although results for returns are statistically insignificant they are correctly signed, which motivates us to examine economic significance. VIX futures and S\&P 500 futures contracts are used as 3 underlying assets for trading volatility and returns, respectively. For VIX futures a cost of $\$ 1.2$ is assumed per contract side (estimate from CBOE for April 2013). For the S\&P 500 futures the cost was assumed at $\$ 3.80$ per round-trip transaction (estimate from CME, effective February 26, 2014). Trading signals are constructed on the basis of medals awarded since the previous working day. Four different medal results are considered: total number of U.S. gold medals, total number of U.S. gold medals in popular sports, total number of gold medals across all countries and total number of gold medals across all countries in popular sports. The results of various active trading strategies against passive strategies for the VIX and S\&P500 are presented in Table 6. The number of contracts per 
trade was determined on the basis of gold medals won over the previous day. So, if U.S. won four gold medals over one day, then according to the first strategy four VIX contracts are shorted. In the case of the S\&P 500 strategies, a long position in futures contracts is taken for each gold medal won. All trading positions last only for one day. The results suggest that all volatility trading strategies are highly profitable and superior to a passive approach. For example, taking a short VIX contract for each U.S. Gold medal won, leads to an average daily return of $1.79 \%$ with a total of 156 contracts, $60.98 \%$ of which are profitable. Overall, the trading strategies allow similar conclusions to those drawn on the basis of the statistical analysis. So, the impact of medals on volatility is significant from both a statistical and economic perspective. The same does not hold for the impact of medals on returns since they do not lead to any significant results.

\subsection{Hypothesis II: Sports success has a positive effect on investor sentiment}

In this section we examine the association between the Olympic Games and direct measures of sentiment. We are limited by the availability of data and analyse only the U.S. using five different measures: the Michigan Consumer Sentiment Index, the Wurgler sentiment index, the Dow Jones Economic Sentiment Indicator (ESI), the IPSOS Global Primary Consumer Sentiment Index (PCSI) and the American Association of Individual Investors Investor Sentiment Survey (AAII). The first four are recorded at a monthly interval while the last is in weekly frequency. We perform our analysis over the complete sample available and over subsamples in order to examine the stability of the results.

We deseasonalise all sentiment indices (SENT) using a regression against a monthly dummy in order to remove any calendar regularities. We then regress the residuals $\mathrm{z}_{\mathrm{t}}$ from 
this regression against Olympic game variables. In the case of the monthly indices the number

of medals cannot be used so we only consider a dummy variable which takes the value of unity during Olympic Game months. Correspondence is not always perfect since Olympic Games do not cover only one or a whole calendar month. We include a dummy for each month if the Olympics cover at least two weeks over that month. In the case of the weekly AAII sentiment index, we only include the number of medals won (GOLD), by the U.S. and all countries in aggregate, over the previous week. We also used the number of medals of the same week and obtained similar results (results available upon request).

Results for the monthly indices and the weekly index are given in Table 7 and Table 8, respectively. In all cases, the Olympics appear to have a positive impact on monthly sentiment but this link is statistically insignificant. For the weekly index, the effect of medals on sentiment tends to be negative but again no relationship is significant. In line with the literature, these results suggest that the Olympic Games and successes do not lead to a stronger bullish sentiment amongst consumers and investors.

\subsection{Hypothesis III: Sports success has a negative effect on investor attention}

Finally, we investigate if the Olympic Games have an impact on investor attention for the countries in our sample on the basis of the Search Volume Index (SVI) which is based on the intensity of queries on Google (see also Da et al., 2011; Vlastakis and Markellos, 2012). Specifically, we investigate market-wide attention on the basis of SVIs for queries related to different index names. For example, we use the SVI of "S\&P 500" in order to measure the market attention for US. In line with the approach of Vlastakis and Markellos, (2012), raw daily SVIs for each country $i$ are logarithmically transformed and deseasonalised using 
dummies for each month of the year. As previously, we then regress the residuals from this regression against the number of medals a country won over the previous day. The results in Table 9 suggest that the attention of investors depends inversely on the number of medals won over the previous day for the stock markets under study. The coefficients are correctly signed in all cases except for France, whereas the estimates are statistically insignificant for France and Japan. Moreover, we obtain similar results if we use number of medals from the same day rather than previous days.

Overall, the results reject our second hypothesis and lend support to our third hypothesis. Combined with the results and discussion in the previous section, the analysis suggests that the significant impact of Olympic success on market activity is the result of investor inattention rather than a shift in mood.

\section{Conclusions}

This paper analyses two potential drivers of investment behaviour, sentiment and attention, by investigating the Summer Olympic performance for eight participating countries and five sponsoring firms. The results show that medals have a negative impact on trading volumes and volatility which is statistically and economically significant. These findings are in line with theories of attention but cannot be explained easily on the basis of sports sentiment. Furthermore, we find a positive relationship between medals and a direct measure of investor inattention for all sample countries. However, no significant link was found between Olympics and investor sentiment on the basis of five different indicators. We conclude that Olympic Games and medals affect the attention of investors but not their mood. 
The recommendation of our paper is that researchers should pay more attention to "attention" when analysing "sentiment". We study investor inattention and sentiment in the context of sports events and performance. However, another empirical setting which is widely used in the behavioural finance literature is related to the weather and environmental conditions. It could be that the positive impact of sunny weather on returns is related also to investor inattention rather than mood. This possibility is first discussed in Symeonidis et al. (2010) as an alternative rational explanation for the negative impact of poor weather on volatility. The literature suggests that the impact of weather on market activity is likely to be complex. Goetzmann and Zhu (2005) report that in order to beat the rush, market participants tend to leave early on rainy days which could have a negative effect on impact due to less time devoted to work. However, Connolly (2008) show that workers tend to work longer hours during rainy days (see also Hagn and Maennig, 2008). Loughran and Schultz (2004) show that trading volume is lower during blizzards in a city due to travel and weather disruptions. Zivin and Neidell (2014) show the effect of daily temperature shocks on the allocation of time to labor as well as leisure activities. Lee et al. (2014) use arguments from cognitive psychology along with field and lab data to show that bad weather increases productivity by eliminating potential cognitive distractions related to good weather. Hamermesh et al. (2008) argue that daylight and time zones can induce temporal coordination of economic activities and affect timing. More research is justified in order to better understand the interaction of investor attention and sentiment in financial market. 


\section{References}

Andrei, D., Hasler, M., "Investor attention and stock market volatility", Review of Financial Studies 28, no.1 (2015): 33-72.

Ashton, J. K., Gerrard, B., Hudson, R., "Economic impact of national sporting success: evidence from the London Stock Exchange", Applied Economics Letters 10, no. 12(2003): $783-785$.

Baker, M., Wurgler, J., "Investor sentiment in the stock market", Journal of Economic Perspectives 21, no. 2 (2007): 129-151.

Barber, B. M., Odean, T., “All that glitters: The effect of attention and news on the buying behavior of individual and institutional investors", Review of Financial Studies 21, no. 2 (2008): 785-818.

Barberis, N., Shleifer, A., Vishny, R., “A model of investor sentiment”, Journal of Financial Economics 49, no.3 (1998): 307-343.

Barberis, N., Thaler, R., “A survey of behavioral finance”, (2002): Working Paper (Series No. 9222, National Bureau of Economic Research)

Bathia, D., and Bredin, D., "An examination of investor sentiment effect on G7 stock market returns.” European Journal of Finance 19, no. 9 (2013): 909-937.

Bernard, A. B., Busse, M. R., "Who wins the Olympic Games: Economic resources and medal totals", Review of Economics and Statistics 86, no. 1 (2004): 413-417.

Bernile, G., Lyandres, E., "Understanding investor sentiment: the case of soccer”, Financial Management 40, no. 2, (2011):357-380.

Boyle, G., Walter, B., "Reflected glory and failure: International sporting success and the stock market", Applied Financial Economics 13, no. 3 (2003): 225-235.

Brown, A., "Information processing constraints and asset mispricing", Economic Journal 124, no. 575 (2014): 245-268.

Brown, G. W., Cliff, M. T., "Investor sentiment and the near-term stock market”, Journal of Empirical Finance 11, no. 1 (2004): 1-27. 
Chang, S. C., Chen, S. S., Chou, R. K., Lin, Y. H., "Local sports sentiment and returns of locally headquartered stocks: A firm-level analysis”, Journal of Empirical Finance 19, no. 3 (2012): 309-318.

Cohen, L., Frazzini, A., "Economic links and predictable returns”, Journal of Finance 63, no. 4 (2008): 1977-2011.

Coakley, J., Dotsis, G., Liu, X. and Zhai, J. "Investor sentiment and value and growth stock index options.” European Journal of Finance 20, no. 12 (2014): 1211-1229.

Connolly, M., "Here comes the rain again: Weather and the intertemporal substitution of leisure", Journal of Labor Economics 26, no. 1 (2008):73-100.

Corwin, S. A., Coughenour, J. F., "Limited attention and the allocation of effort in securities trading”, Journal of Finance 63, no. 6 (2008): 3031-3067.

Cumming, D., Dai, N., "Fund size, limited attention and valuation o f venture capital backed firms", Journal of Empirical Finance 18, no. 1 (2011):2-15.

Da, Z., Engelberg, J., Gao, P., "In search of attention”, Journal of Finance 66, no. 5 (2011): 1461-1499.

Dawson, P., Downward, P., Mills, T. C., "Olympic news and attitudes towards the Olympics: a compositional time-series analysis of how sentiment is affected by events", Journal of Applied Statistics 41, no. 6 (2014): 1307-1314.

DCMS/ Strategy Unit, “Game plan: A strategy for delivering governments sport and physical activity objectives", (Department for Culture, Media and Sport/ Strategy Unit, 2002).

De Long, J. B., Shleifer, A., Summers, L. H., Waldmann, R. J., "Noise trader risk in financial markets", Journal of Political Economy 98, no. 4 (1990): 703-738.

DellaVigna, S., Pollet, J. M., "Investor inattention and Friday earnings announcements", Journal of Finance 64, no. 2 (2009): 709-749.

Edmans, A., Garcia, D., Norli, Ø., "Sports sentiment and stock returns”, Journal of Finance 62, no. 4 (2007): 1967-1998.

Ehrmann, M., Jansen, D. J., “The pitch rather than the pit: investor inattention during FIFA world cup matches", (2012): Working Paper (European Central Bank).

Farrell, K. A., Frame, W. S., “The value of Olympic sponsorships: who is capturing the gold?”, Journal of Market-Focused Management 2, no. 2 (1997): 171-182. 
Ferris, S. P., Hao, Q., Liao, M.Y., "The effect of issuer conservatism on IPO pricing and performance", Review of Finance 17, no. 3 (2013): 993-1027.

Frieder, L., Subrahmanyam, A., "Nonsecular regularities in returns and volume”, Financial Analysts Journal 60, no. 4 (2004): 29-34.

Gilbert, T., Kogan, S., Lochstoer, L., Ozyildirim, A., "Investo $r$ inattention and the market impact of summary statistics", Management Science 58, no. 2 (2012): 336-350.

Glosten, L. R., Jagannathan, R., Runkle, D. E., "On the relation between the expected value and the volatility of the nominal excess return on stocks", Journal of Finance 48, no. 5 (1993): 1779-1801.

Goetzmann, W. N., Zhu, N., "Rain or shine: where is the weather effect?”, European Financial Management 11, no. 5 (2005): 559-578.

Hagn, F., Maennig, W., "Employment effects of the football World Cup 1974 in Germany", Labour Economics 15, no. 5 (2008): 1062-1075.

Hamermesh, D. S., Myers, C. K., Pocock, M. L., 2008, "Cues for timing and coordination: Latitude, letterman, and longitude", Journal of Labor Economics 26, no. 2 (2008): 223-246.

Hanke, M., Kirchler, M., “ Football championships and jersey sponsors” stock prices: an empirical investigation", European Journal of Finance 19, no. 3 (2013): 228-241.

Hirshleifer, D., Lim, S. S., Teoh, S. H., “ Limited investor attention and stock market misreactions to accounting information”, Review of Asset Pricing Studies 1, no. 1 (2011): 3573.

Hirshleifer, D., Shumway, T., “Good day sunshine: Stock returns and the weather”, Journal of Finance 58, no. 3 (2003): 1009-1032.

Huberman, G., Regev, T., “Contagious speculation and a cure for cancer: A nonevent that made stock prices soar", Journal of Finance 56, no. 1 (2001): 387-396.

Jacobs, H., Weber, M., “The trading volume impact of local bias: Evidence from a natural experiment", Review of Finance 16, no.4 (2012): 867-901.

Jones, M. V., Coffee, P., Sheffield, D., Yanguiez, M., Barker, J. B., "Just a game? Changes in English and Spanish soccer fans' emotions in the 2010 World Cup", Psychology of Sport and Exercise 13, no. 2 (2012): 162-169. 
Kacperczyk, M. T., Van Nieuwerburgh, S., Veldkamp, L., “A rational theory of mutual funds' attention allocation", (2014): Working Paper (No.2451/28347, NYU)

Kahneman, D., “Attention and effort”, Prentice-Hall series in experimental psychology, (Prentice-Hall, New Jersey, 1973).

Kahneman, D., Tversky, A., "Prospect theory: An analysis of decision under risk". Econometrica 47, no.2 (1979): 263-291.

Kamstra, M. J., Kramer, L. A., Levi, M. D., 2003, "Winter blues: A sad stock market cycle”, American Economic Review 93, no. 1 (2003): 324-343.

Kaplanski, G., Levy, H., "Exploitable predictable irrationality: The FIFA world cup effect on the U.S. stock market", Journal of Financial and Quantitative Analysis 45, no. 2 (2010a): $535-553$.

Kaplanski, G., Levy, H., "Sentiment and stock prices: The case of aviation disasters", Journal of Financial Economics 95, no. 2 (2010b): 174-201.

Kavetsos, G., Szymanski, S., 2010, "National well-being and international sports events”, Journal of Economic Psychology 31, no. 2 (2010): 158-171.

Krueger, T. M., Kennedy, W. F., 1990, “An examination of the super bowl stock market predictor", Journal of Finance 45, no. 2 (1990): 691-697.

Lee, J. J., Gino, F., Staats, B. R., "Rainmakers: Why bad weather means good productivity", Journal of Applied Psychology 99, no. 3 (2014): 504-513.

Lemmon, M., Portniaguina, E., "Consumer confidence and asset prices: Some empirical evidence", Review of Financial Studies 19, no. 4 (2006): 1499-1529.

Loughran, T., McDonald, B., "When is a liability not a liability? Textual analysis, dictionaries, and 10-ks", Journal of Finance 66, no. 1 (2011): 35-65.

Loughran, T., Schultz, P., "Weather, stock returns, and the impact of localized trading behavior", Journal of Financial and Quantitative Analysis 39, no. 2 (2004): 343-364.

Lozano, F. A., "The flexibility of the workweek in the United States: evidence from the FIFA World Cup", Economic Inquiry 49, no. 2 (2011): 512-529. 
Mishra, V., Smyth, R., "An examination of the impact of India's performance in one-day cricket internationals on the Indian stock market", Pacific-Basin Finance Journal 18, no. 3 (2010): 319-334.

Miyazaki, A. D., Morgan, A. G., “Assessing market value of event sponsoring: corporate Olympic sponsorships", Journal of Advertising Research 41, no. 1 (2001): 9-16.

Newey, W. K., West, K. D., “A simple, positive semidefinite heteroskedasticity and autocorrelation consistent covariance-matrix", Econometrica 55, no.3 (1987): 703-708.

Ofcom, "The London 2012 Olympic Games: media consumption", (Office of Communications, 2012).

Oxford Economics, "The economic impact of London 2012 Olympic and Paralympic Games", (Oxford Economics, 2012).

Palomino, F., Renneboog, L., Zhang, C., "Information salience, investor sentiment, and stock returns: The case of British soccer betting", Journal of Corporate Finance 15, no. 3 (2009): $368-387$.

Pashler, H., "Dual-task interference in simple tasks: data and theory", Psychological Bulletin 116, no. 2 (1994): 220-244.

Peng, L., Xiong, W., “Investor attention, overconfidence and category learning”, Journal of Financial Economics 80, no. 3 (2006): 563-602.

Ross, L., "The intuitive psychologist and his shortcomings: Distortions in the attribution process". In Leonard, B. (Ed.), Advances in experimental social psychology ( Vol. 10. Academic Press, New York, 1977), 173-220.

Saunders Jr, E. M., “Stock prices and wall street weather”, American Economic Review 83, no. 5 (1993): 1337-1345.

Schmidt, D., "Investors" attention and stock covariation: Evidence from Google sport searches", (2013): Working Paper (INSEAD).

Schmittmann, J. M., Pirschel, J., Meyer, S., Hackethal, A., “The impact of weather on German retail investors", Review of Finance 19, no. 3 (2015): 1143-1183

Shiller, R. J., "From efficient markets theory to behavioral finance", Journal of Economic Perspectives 17, no. 1 (2003): 83-104.

Simon, H. A., Models of man; social and rational, (Wiley, New York, 1957). 
Sims, C. A., "Implications of rational inattention", Journal of monetary Economics 50, no. 3 (2003): 665-690.

Symeonidis, L., Daskalakis, G., Markellos, R. N., "Does the weather affect stock market volatility?", Finance Research Letters 7, no. 4 (2010): 214-223.

Tetlock, P. C., "Giving content to investor sentiment: The role of media in the stock market", Journal of Finance 62, no. 3 (2007): 1139-1168.

Vazsonyi, M., "Overview of quantitative news interpretation methods applied in financial market predictions", Social and Management Sciences 17, no. 1 (2010): 17-29.

Veldkamp, L. L., Information choice in macroeconomics and finance, (Princeton University Press, New Jersey, 2011).

Vlastakis, N., Markellos, R. N., "Information demand and stock market volatility", Journal of Banking and Finance 36, no. 6 (2012): 1808-1821.

Worthington, A. C., "National exuberance: A note on the Melbourne Cup effect in Australian stock returns", Economic Papers 26, no. 2 (2007): 170-179.

Yantis, S., "Control of visual attention”, In Pashler, H. (Ed.), Attention, (University College London Press, London, 1998), 223-256.

Yuan, K., Zheng, L., Zhu, Q., “Are investors moonstruck? Lunar phases and stock returns”, Journal of Empirical Finance 13, no. 1 (2006): 1-23.

Zivin, J. G., Neidell, M., "Temperature and the allocation of time: Implications for climate change", Journal of Labor Economics 32, no. 1 (2014): 1-26.

\footnotetext{
${ }^{1}$ It is surprising that this possibility has not been entertained yet in the financial literature, although it is an idea that has been popular since antiquity. For example, the phrase panem et circenses - bread and circuses, the latter having the meaning of public games and other of mass spectacles - is popular since Roman times as a figure of speech to describe how a major sports event can be used to appease a specific group of people by diverting their attention. The idea is still very popular, as exemplified by Hunger Games, the popular trilogy by Suzanne Collins which was recently turned into a movie.

${ }^{2}$ Crosschecks where performed across several websites in order to ensure the validity of the results for the Games of: 2000 (Pandora, Medaltally, CNN sports), 2004 (Yahoo sports, Telegraph), 2008 (Telegraph, BBC) and 2012 ( London 2012 official website).
} 
${ }^{3}$ VIX futures started to trade on 26 March 2004. In order to extend this series so that it covers complete sample of four Olympic Games, we used VIX spot data for the period between 15 September 2000 and 2 October 2000 as a proxy of the futures series. 
Table 1: Variable abbreviations and descriptions

\begin{tabular}{|c|c|}
\hline Abbreviation & Description \\
\hline $\begin{array}{l}\text { US, UK, FRA, } \\
\text { AUS, NLD, GER, } \\
\text { KOR, JPN }\end{array}$ & $\begin{array}{l}\text { Country label for US, United Kingdom, France, Australia, Netherlands, } \\
\text { Germany, South Korea, Japan }\end{array}$ \\
\hline $\mathrm{R}$ & $\begin{array}{l}\text { Stock market index logarithmic return (S\&P500: US, FTSE:UK, } \\
\text { CAC:FR, ASX: AUS, AEX: NL, DAX: GRM, KOSPI: SK, NIKKEI: } \\
\text { JPN) }\end{array}$ \\
\hline Games & $\begin{array}{l}\text { Dummy variable denoting the Olympic market period for each } \\
\text { particular country }\end{array}$ \\
\hline MSCI & $\begin{array}{l}\text { Morgan Stanley stock market index for global stock funds in local } \\
\text { currency }\end{array}$ \\
\hline RV & $\begin{array}{l}\text { Realised volatility estimate } \\
\text { Implied Volatility Index (VIX: US, VFTSE:UK, VCAC:FR, SPAVIX: } \\
\text { AUS, VAEX: NL, VDAX: GRM, VKOSPI: SK, VXJ: JPN) }\end{array}$ \\
\hline Med & Total number of medals \\
\hline TMed & Total number of medals from eight countries \\
\hline Gold & Number of Gold Medals \\
\hline TGold & Total number of Gold Medals from eight countries \\
\hline Silver & Number of Silver Medals \\
\hline $\begin{array}{l}\text { TSilver } \\
\text { Bronze }\end{array}$ & Total number of Silver Medals from eight countries \\
\hline TBronze & Number of Bronze Medals \\
\hline Popular & Total number of Bronze Medals from eight countries \\
\hline $\begin{array}{l}\text { TPopular } \\
\text { KO, MCD, }\end{array}$ & $\begin{array}{l}\text { Total number of medals from Popular Sports } \\
\text { Total number of medals from Popular Sports from eight countries }\end{array}$ \\
\hline PC, VIS, SAM & Coca Cola, McDonalds, Panasonic, Visa, Samsung \\
\hline VLM & Trading volume for each country in USD \\
\hline SVI & Search Volume Index \\
\hline
\end{tabular}


Table 2: Descriptive Statistics of Stock Market Returns and Firm Returns

\begin{tabular}{lrrrrrrrr}
\hline Return & Mean & Mean' & St.Dev & Min & Max & Skewness & Kurtosis & JB \\
\hline US & $-1.56 \mathrm{E}-05$ & 0.0015 & 0.0136 & -0.0947 & 0.1096 & -0.1531 & 10.5288 & $7,101.89$ \\
UK & $-3.74 \mathrm{E}-05$ & 0.0011 & 0.0131 & -0.0926 & 0.0938 & -0.1174 & 8.7981 & $4,266.43$ \\
FRA & $-2.08 \mathrm{E}-04$ & 0.0010 & 0.0159 & -0.0947 & 0.1059 & 0.0593 & 7.6960 & $2,807.09$ \\
AUS & $8.92 \mathrm{E}-05$ & 0.0006 & 0.0107 & -0.0870 & 0.0563 & -0.4649 & 8.7701 & $4,314.02$ \\
NLD & $-2.30 \mathrm{E}-04$ & 0.0016 & 0.0160 & -0.0959 & 0.1003 & -0.0437 & 8.6302 & $4,032.07$ \\
GER & $1.84 \mathrm{E}-06$ & 0.0008 & 0.0165 & -0.0743 & 0.1080 & 0.0378 & 6.9898 & $2,017.71$ \\
KOR & $3.71 \mathrm{E}-04$ & 0.0010 & 0.0168 & -0.1280 & 0.1128 & -0.5081 & 7.8087 & $2,970.19$ \\
JPN & $-1.94 \mathrm{E}-04$ & 0.0001 & 0.0159 & -0.1211 & 0.1323 & -0.3770 & 9.7370 & $5,612.37$ \\
\hline KO & 0.0002 & 0.0028 & 0.0135 & -0.1060 & 0.1303 & 0.0077 & 12.2603 & $10,729.84$ \\
MCD & 0.0005 & 0.0038 & 0.0156 & -0.1371 & 0.0898 & -0.1860 & 8.5242 & $3,834.52$ \\
PC & -0.0004 & 0.0044 & 0.0211 & -0.2045 & 0.1739 & -0.0649 & 9.4553 & $5,214.44$ \\
VIS & 0.0010 & 0.0038 & 0.0260 & -0.1467 & 0.2501 & 0.7756 & 14.4211 & $6,182.92$ \\
SAM & 0.0005 & 0.0003 & 0.0246 & -0.1480 & 0.1398 & -0.0239 & 6.9460 & $1,914.87$ \\
\hline
\end{tabular}

JB is the Jarque-Bera (1980) normality test statistic. All values are highly significant at conventional levels. Mean' is the average return of local stock market and sponsor firms during the Olympic Period. 

Table 3: The impact of Olympic medals on trading volumes

\begin{tabular}{|c|c|c|c|c|c|}
\hline Country & GMed & Med & SHed & BMed & MedP \\
\hline US & $\begin{array}{c}-0.0295 * * * \\
(-3.2868)\end{array}$ & $\begin{array}{c}-0.0107 * * \\
(-2.3947)\end{array}$ & $\begin{array}{c}-0.0261 * * \\
(-2.0221)\end{array}$ & $\begin{array}{c}-0.0195 \\
(-1.5511)\end{array}$ & $\begin{array}{c}-0.0163 * * \\
(-2.0899)\end{array}$ \\
\hline UK & $\begin{array}{c}-0.0213 \\
(-1.2370)\end{array}$ & $\begin{array}{c}-0.0125 \\
(-1.3052)\end{array}$ & $\begin{array}{c}-0.0399 \\
(-1.1575)\end{array}$ & $\begin{array}{c}-0.0392 \\
(-1.3203)\end{array}$ & $\begin{array}{c}-0.0206 \\
(-0.8659)\end{array}$ \\
\hline FRA & $\begin{array}{c}-0.0925 * * \\
(-2.3349)\end{array}$ & $\begin{array}{c}-0.0260 * * \\
(-2.2352)\end{array}$ & $\begin{array}{c}-0.0385 \\
(-1.2257)\end{array}$ & $\begin{array}{c}-0.0377 \\
(-1.2743)\end{array}$ & $\begin{array}{c}0.0248 \\
(0.8487)\end{array}$ \\
\hline AUS & $\begin{array}{c}-0.0116 \\
(-0.2269)\end{array}$ & $\begin{array}{c}-0.0145 \\
(-0.8224)\end{array}$ & $\begin{array}{c}-0.0552 * * \\
(-2.0808)\end{array}$ & $\begin{array}{c}-0.0098 \\
(-0.2357)\end{array}$ & $\begin{array}{l}0.0127 \\
(0.723)\end{array}$ \\
\hline NLD & $\begin{array}{c}-0.1109 * * * \\
(-3.2309)\end{array}$ & $\begin{array}{c}-0.0445 * * \\
(-2.2635)\end{array}$ & $\begin{array}{c}-0.1081 * * \\
(-2.7234)\end{array}$ & $\begin{array}{c}0.0283 \\
(0.8392)\end{array}$ & $\begin{array}{c}0.0034 \\
(0.0569)\end{array}$ \\
\hline GER & $\begin{array}{c}-0.0668 * * \\
(-2.4668)\end{array}$ & $\begin{array}{c}-0.0282 * * * \\
(-3.0729)\end{array}$ & $\begin{array}{c}-0.0506 * * \\
(-1.9726)\end{array}$ & $\begin{array}{c}-0.0792 * * * \\
(-4.1994)\end{array}$ & $\begin{array}{c}-0.0803 * * \\
(-2.1302)\end{array}$ \\
\hline KOR & $\begin{array}{c}-0.0732 * * \\
(-2.2068)\end{array}$ & $\begin{array}{c}-0.0279 * * \\
(-2.0196)\end{array}$ & $\begin{array}{c}-0.0205 \\
(-0.7913)\end{array}$ & $\begin{array}{c}-0.0832 * * \\
(-2.1555)\end{array}$ & $\begin{array}{c}0.0792 * * \\
(2.1852)\end{array}$ \\
\hline JPN & $\begin{array}{c}0.0006 \\
(0.0187)\end{array}$ & $\begin{array}{c}-0.0133 \\
(-0.8373)\end{array}$ & $\begin{array}{c}-0.0241 \\
(-1.4652)\end{array}$ & $\begin{array}{c}-0.0353 \\
(-1.1187)\end{array}$ & $\begin{array}{c}-0.0279 \\
(-1.4280)\end{array}$ \\
\hline TUS & $\begin{array}{c}-0.0088 * * * \\
(-2.9044)\end{array}$ & $\begin{array}{c}-0.0029 * * * \\
(-2.7868)\end{array}$ & $\begin{array}{c}-0.0083 * * * \\
(-2.7695)\end{array}$ & $\begin{array}{c}-0.0078 * * \\
(-2.4863)\end{array}$ & $\begin{array}{c}-0.0066 * * \\
(-2.3002)\end{array}$ \\
\hline $\mathrm{KO}$ & $\begin{array}{c}-0.0263 \\
(-1.6396)\end{array}$ & $\begin{array}{c}-0.0059 \\
(-0.7676)\end{array}$ & $\begin{array}{c}-0.0072 \\
(-0.3652)\end{array}$ & $\begin{array}{c}-0.0062 \\
(-0.2664)\end{array}$ & $\begin{array}{c}-0.0103 \\
(-0.8877)\end{array}$ \\
\hline MCD & $\begin{array}{c}-0.0685^{* * *} \\
(-2.9348)\end{array}$ & $\begin{array}{c}-0.0243 * * \\
(-2.2204)\end{array}$ & $\begin{array}{l}-0.0522 * \\
(-1.7193)\end{array}$ & $\begin{array}{l}-0.0543 * \\
(-1.7522)\end{array}$ & $\begin{array}{l}-0.0296 * \\
(-1.9214)\end{array}$ \\
\hline $\mathrm{PC}$ & $\begin{array}{l}-0.0175 \\
(-0.428)\end{array}$ & $\begin{array}{c}-0.0037 \\
(-0.1919)\end{array}$ & $\begin{array}{l}0.0084 \\
(0.185)\end{array}$ & $\begin{array}{c}-0.0233 \\
(-0.3841)\end{array}$ & $\begin{array}{c}-0.0090 \\
(-0.3112)\end{array}$ \\
\hline VIS & $-0.0321 * *$ & $-0.0137 * *$ & $-0.0398 *$ & -0.0245 & $-0.0228 * * *$ \\
\hline SAM & $\begin{array}{c}(-1.9561) \\
-0.0940 * * \\
(-2.1648)\end{array}$ & $\begin{array}{c}(-2.0623) \\
-0.0177 \\
(-1.3993)\end{array}$ & $\begin{array}{c}(-1.7351) \\
0.0160 \\
(0.4523)\end{array}$ & $\begin{array}{c}(-1.1889) \\
-0.0310 \\
(-0.5591)\end{array}$ & $\begin{array}{c}(-2.6573) \\
-0.0302 \\
(-0.3126)\end{array}$ \\
\hline Firms & TGMed & TMed & TSMed & TBMed & TMedP \\
\hline $\mathrm{KO}$ & $\begin{array}{l}-0.0059 \\
(-1.0296)\end{array}$ & $\begin{array}{l}-0.0018 \\
(-0.8668)\end{array}$ & $\begin{array}{l}-0.0052 \\
(-0.8610)\end{array}$ & $\begin{array}{l}-0.0043 \\
(-0.6930)\end{array}$ & $\begin{array}{l}-0.0047 \\
(-0.8321)\end{array}$ \\
\hline MCD & $\begin{array}{l}-0.0182 * * \\
(-2.3855)\end{array}$ & $\begin{array}{l}-0.0067 * * * \\
(-2.6167)\end{array}$ & $\begin{array}{l}-0.0198 * * * \\
(-2.8151)\end{array}$ & $\begin{array}{l}-0.0200^{* *} \\
(-2.5096)\end{array}$ & $\begin{array}{l}-0.0147 * * \\
(-2.1734)\end{array}$ \\
\hline PC & $\begin{array}{l}-0.0057 \\
(-0.4012)\end{array}$ & $\begin{array}{l}-0.0021 \\
(-0.4795)\end{array}$ & $\begin{array}{l}-0.0073 \\
(-0.6207)\end{array}$ & $\begin{array}{l}-0.0055 \\
(-0.4190)\end{array}$ & $\begin{array}{l}-0.0024 \\
(-0.1955)\end{array}$ \\
\hline VIS & $\begin{array}{l}-0.0115^{* *} \\
(-2.1506)\end{array}$ & $\begin{array}{l}-0.0040 * * \\
(-2.1526)\end{array}$ & $\begin{array}{l}-0.0113^{*} \\
(-1.9923)\end{array}$ & $\begin{array}{l}-0.0112^{* * *} \\
(-2.1589)\end{array}$ & $\begin{array}{l}-0.0117 * * \\
(-2.1477)\end{array}$ \\
\hline SAM & $\begin{array}{l}-0.0079 * * * \\
(-2.7386)\end{array}$ & $\begin{array}{l}-0.0025^{* *} \\
(-2.4729)\end{array}$ & $\begin{array}{l}-0.0060 * \\
(-1.8609)\end{array}$ & $\begin{array}{l}-0.0078 * * \\
(-2.3051)\end{array}$ & $\begin{array}{l}-0.0086 * * * \\
(-3.2735)\end{array}$ \\
\hline
\end{tabular}

This table gives the value of the coefficients $\mathrm{b}_{\mathrm{i} 1}$ in regression (4) with trading volume as the dependent variable in regression (2), respectively. Numbers in brackets correspond to t-statistics.

Heteroskedasticity and autocorrelation consistent standard errors are estimated using the Newey and West (1987) approach. ***,**,* denote statistical significance at the 1\%, 5\% and $10 \%$ level respectively. When TUS is used, it is the total number of medals for all eight countries, the trading volume corresponds to the US. When analysing firms, the number of medals and volume correspond to the market where the firm is listed. We also use the total number of medals for the eight countries analysed in order to capture a more global effect of medals on firms which may result from international exposure. 
Table 4: The impact of Olympic medals on realized (RV) and implied (IV) volatility

\begin{tabular}{|c|c|c|c|c|c|c|}
\hline & Market & Gold & Med & Silver & Bronze & Popular \\
\hline & US & $\begin{array}{l}-6.47 \mathrm{E}-06^{* *} \\
(-2.1323)\end{array}$ & $\begin{array}{l}-2.53 \mathrm{E}-06 * * \\
(-2.0395)\end{array}$ & $\begin{array}{l}-5.99 \mathrm{E}-06^{*} \\
(-1.7369)\end{array}$ & $\begin{array}{l}-5.91 \mathrm{E}-06 \\
(-1.3332)\end{array}$ & $\begin{array}{l}-2.45 \mathrm{E}-06 \\
(-1.2905)\end{array}$ \\
\hline & UK & $\begin{array}{r}-2.36 \mathrm{E}-06 \\
(-0.7723)\end{array}$ & $\begin{array}{r}-1.39 \mathrm{E}-06 \\
(-1.0375)\end{array}$ & $\begin{array}{l}-2.90 \mathrm{E}-06 \\
(-0.7094)\end{array}$ & $\begin{array}{l}-5.58 \mathrm{E}-06^{*} \\
(-1.7421)\end{array}$ & $\begin{array}{l}-2.87 \mathrm{E}-06 \\
(-0.4832)\end{array}$ \\
\hline & FRA & $\begin{array}{l}-6.25 \mathrm{E}-06 \\
(-1.4008)\end{array}$ & $\begin{array}{r}-2.40 \mathrm{E}-06 \\
(-1.1503)\end{array}$ & $\begin{array}{l}-8.91 \mathrm{E}-06 \\
(-1.6189)\end{array}$ & $\begin{array}{l}1.17 \mathrm{E}-06 \\
(0.1994)\end{array}$ & $\begin{array}{l}-2.95 E-06 \\
(-0.5169)\end{array}$ \\
\hline & AUS & $2.63 \mathrm{E}-05^{* * *}$ & $6.79 \mathrm{E}-06^{* * *}$ & $7.96 \mathrm{E}-06 * *$ & $1.90 \mathrm{E}-05 * * *$ & $-2.00 \mathrm{E}-07$ \\
\hline & & $(9.6316)$ & $(4.9323)$ & $(2.3015)$ & $(4.2385)$ & $(-0.0471)$ \\
\hline \multirow[t]{9}{*}{$\mathbf{R V}$} & NLD & $\begin{array}{l}-2.28 \mathrm{E}-05^{* * *} \\
(-2.5821)\end{array}$ & $\begin{array}{l}-1.28 \mathrm{E}-05^{* *} \\
(-2.4951)\end{array}$ & $\begin{array}{l}-2.49 \mathrm{E}-05^{* *} \\
(-2.4186)\end{array}$ & $\begin{array}{l}-5.21 \mathrm{E}-06 \\
(-0.6886)\end{array}$ & $\begin{array}{r}1.36 \mathrm{E}-05 \\
(0.9854)\end{array}$ \\
\hline & GER & $\begin{array}{l}-2.81 \mathrm{E}-05^{* * * *} \\
(-3.0275)\end{array}$ & $\begin{array}{l}-5.78 \mathrm{E}-06^{*} \\
(-1.8760)\end{array}$ & $\begin{array}{l}-6.80 \mathrm{E}-06 \\
(-0.5948)\end{array}$ & $\begin{array}{l}-8.90 \mathrm{E}-06 \\
(-0.8131)\end{array}$ & $\begin{array}{l}-229 \mathrm{E}-05^{*} \\
(-1.8108)\end{array}$ \\
\hline & KOR & $\begin{array}{l}-9.58 \mathrm{E}-06 \\
(-1.5441)\end{array}$ & $\begin{array}{l}-3.14 \mathrm{E}-06 \\
(-1.1492)\end{array}$ & $\begin{array}{l}3.85 \mathrm{E}-07 \\
(0.0889)\end{array}$ & $\begin{array}{l}-1.09 \mathrm{E}-05^{* *} \\
(-2.1591)\end{array}$ & $\begin{array}{l}-1.13 \mathrm{E}-05 \\
(-0.9621)\end{array}$ \\
\hline & JPN & $\begin{array}{l}-5.54 \mathrm{E}-06 \\
(-1.6395)\end{array}$ & $\begin{array}{l}-1.75 \mathrm{E}-06 \\
(-0.8195)\end{array}$ & $\begin{array}{l}-4.84 \mathrm{E}-06^{*} \\
(-1.9455)\end{array}$ & $\begin{array}{l}1.70 \mathrm{E}-07 \\
(0.0281)\end{array}$ & $\begin{array}{l}-6.68 \mathrm{E}-06^{*} \\
(-1.8929)\end{array}$ \\
\hline & TUS & $\begin{array}{l}-1.98 \mathrm{E}-06^{* *} \\
(-2.0685)\end{array}$ & $\begin{array}{l}-6.51 \mathrm{E}-07 * * \\
(-2.1270)\end{array}$ & $\begin{array}{l}-1.95 \mathrm{E}-06^{* *} \\
(-2.2833)\end{array}$ & $\begin{array}{l}-1.70 \mathrm{E}-06^{*} \\
(-1.8213)\end{array}$ & $\begin{array}{c}-1.27 \mathrm{E}-06^{*} \\
(-1.9168)\end{array}$ \\
\hline & US & $\begin{array}{l}-8.91 \mathrm{E}-06 * * * \\
(-3.0842)\end{array}$ & $\begin{array}{l}-3.38 \mathrm{E}-06^{* * *} \\
(-2.4034)\end{array}$ & $\begin{array}{l}-7.03 \mathrm{E}-06^{*} \\
(-1.8103)\end{array}$ & $\begin{array}{l}-9.13 \mathrm{E}-06^{* *} \\
(-2.1787)\end{array}$ & $\begin{array}{l}-4.40 \mathrm{E}-06 * * \\
(-2.2181)\end{array}$ \\
\hline & UK & $\begin{array}{l}-8.36 \mathrm{E}-06^{*} \\
(-1.8607)\end{array}$ & $\begin{array}{l}-4.61 \mathrm{E}-06^{* *} \\
(-2.0813)\end{array}$ & $\begin{array}{l}-1.36 \mathrm{E}-05^{* *} \\
(-2.1143)\end{array}$ & $\begin{array}{l}-1.42 \mathrm{E}-05^{* *} \\
(-2.1526)\end{array}$ & $\begin{array}{l}-3.82 \mathrm{E}-06 \\
(-0.3880)\end{array}$ \\
\hline & FRA & $\begin{array}{l}-2.16 \mathrm{E}-05^{* * *} \\
(-3.9424)\end{array}$ & $\begin{array}{l}-7.69 \mathrm{E}-06^{* * * *} \\
(-3.3655)\end{array}$ & $\begin{array}{l}-1.24 \mathrm{E}-05^{* * *} \\
(-2.6772)\end{array}$ & $\begin{array}{l}-1.41 \mathrm{E}-05^{*} \\
(-1.6977)\end{array}$ & $\begin{array}{r}2.23 \mathrm{E}-06 \\
(0.3070)\end{array}$ \\
\hline & AUS & $\begin{array}{l}1.51 \mathrm{E}-06 \\
(0.1003)\end{array}$ & $\begin{array}{l}-3.39 \mathrm{E}-06 \\
(-0.7430)\end{array}$ & $\begin{array}{l}-9.14 \mathrm{E}-06 \\
(-1.1965)\end{array}$ & $\begin{array}{l}-8.92 \mathrm{E}-06 \\
(-0.8987)\end{array}$ & $\begin{array}{l}2.07 \mathrm{E}-05 \\
(2.2783)\end{array}$ \\
\hline \multirow[t]{5}{*}{ IV } & NLD & $\begin{array}{l}-5.10 \mathrm{E}-05^{* * *} \\
(-2.8760)\end{array}$ & $\begin{array}{l}-2.74 \mathrm{E}-05^{* * * *} \\
(-2.6227)\end{array}$ & $\begin{array}{l}-3.39 \mathrm{E}-05^{* *} \\
(-2.1781)\end{array}$ & $\begin{array}{l}-2.42 \mathrm{E}-05 \\
(-1.4977)\end{array}$ & $\begin{array}{r}-6.54 \mathrm{E}-06 \\
(-0.5624)\end{array}$ \\
\hline & GER & $\begin{array}{l}-2.14 \mathrm{E}-05^{* *} \\
(-2.4126)\end{array}$ & $\begin{array}{l}-9.56 \mathrm{E}-06^{* * * *} \\
(-3.0823)\end{array}$ & $\begin{array}{l}-1.96 \mathrm{E}-05^{* *} \\
(-2.3725)\end{array}$ & $\begin{array}{l}-2.52 \mathrm{E}-05^{* *} \\
(-3.9920)\end{array}$ & $\begin{array}{l}-2.26 \mathrm{E}-05^{* *} \\
(-2.3239)\end{array}$ \\
\hline & KOR & $\begin{array}{l}-9.76 \mathrm{E}-06^{*} \\
(-1.8971)\end{array}$ & $\begin{array}{l}-4.05 \mathrm{E}-06^{* *} \\
(-2.1672)\end{array}$ & $\begin{array}{l}-5.19 \mathrm{E}-06 \\
(-1.0934)\end{array}$ & $\begin{array}{l}-1.01 \mathrm{E}-05^{* *} \\
(-2.2775)\end{array}$ & $\begin{array}{l}-1.03 \mathrm{E}-05 \\
(-0.8131)\end{array}$ \\
\hline & JPN & $\begin{array}{l}-7.46 \mathrm{E}-06 \\
(-1.1308)\end{array}$ & $\begin{array}{l}-8.24 \mathrm{E}-06 * * * \\
(-3.1641)\end{array}$ & $\begin{array}{l}-1.65 \mathrm{E}-05^{* *} \\
(-2.4126)\end{array}$ & $\begin{array}{l}-1.54 \mathrm{E}-05 * * * \\
(-2.8441)\end{array}$ & $\begin{array}{l}-1.41 \mathrm{E}-05 * * * \\
(-3.5145)\end{array}$ \\
\hline & TUS & $\begin{array}{l}-2.79 \mathrm{E}-06 * * * \\
(-2.7072)\end{array}$ & $\begin{array}{l}-9.30 \mathrm{E}-07 * * * \\
(-2.6617)\end{array}$ & $\begin{array}{l}-2.53 \mathrm{E}-06^{* *} \\
(-2.5109)\end{array}$ & $\begin{array}{l}-2.74 \mathrm{E}-06^{* * * *} \\
(-2.6383)\end{array}$ & $\begin{array}{l}-1.63 \mathrm{E}-06^{* *} \\
(-2.0250)\end{array}$ \\
\hline
\end{tabular}

This table gives the value of the coefficients $b_{i 1}$ in regression (4) with realised and implied volatility as the dependent variable in regression (3), respectively. Numbers in brackets correspond to t-statistics. Heteroskedasticity and autocorrelation consistent standard errors are estimated using the Newey and West (1987) approach. $* * *, * * *$ denote statistical significance at the $1 \%, 5 \%$ and $10 \%$ level respectively. When TUS is used, which is the total number of medals for all eight countries, the realised and implied volatility correspond to the US. 
Table 5: The impact of Olympic medals on historical volatility

\begin{tabular}{|c|c|c|c|c|c|}
\hline Market & Gold & Total & Silver & Bronze & Popular \\
\hline US & $\begin{array}{l}-1.70 \mathrm{E}-05^{* * *} \\
(-269.6852)\end{array}$ & $\begin{array}{l}-4.48 \mathrm{E}-07^{* *} \\
(-2.3188)\end{array}$ & $\begin{array}{l}-1.25 \mathrm{E}-06^{* * *} \\
(-10.4413)\end{array}$ & $\begin{array}{l}-1.58 \mathrm{E}-06 * * * \\
(-9.1287)\end{array}$ & $\begin{array}{l}-6.35 \mathrm{E}-07 \text { *** } \\
(-4.8870)\end{array}$ \\
\hline UK & $\begin{array}{l}-2.30 \mathrm{E}-06^{* * *} \\
(-26.3963)\end{array}$ & $\begin{array}{l}-1.06 \mathrm{E}-05^{* * * *} \\
(-13.8386)\end{array}$ & $\begin{array}{l}-3.69 \mathrm{E}-06^{* * *} \\
(-10.8105)\end{array}$ & $\begin{array}{l}-3.09 \mathrm{E}-06^{* * * *} \\
(-9.7972)\end{array}$ & $\begin{array}{l}-4.91 \mathrm{E}-06 * * * \\
(-13.1744)\end{array}$ \\
\hline FRA & $\begin{array}{l}-7.47 \mathrm{E}-05^{* * *} \\
(-13.9220)\end{array}$ & $\begin{array}{l}-1.33 \mathrm{E}-06^{*} \\
(-1.7493)\end{array}$ & $\begin{array}{l}-4.30 \mathrm{E}-05 \\
(-1.0983)\end{array}$ & $\begin{array}{l}-5.07 \mathrm{E}-05^{* * *} \\
(-2.3294)\end{array}$ & $\begin{array}{l}-5.07 \mathrm{E}-06 \\
(-1.5266)\end{array}$ \\
\hline AUS & $\begin{array}{l}-2.40 \mathrm{E}-05 \\
(-0.5358)\end{array}$ & $\begin{array}{l}-3.90 \mathrm{E}-07 \\
(-1.5621)\end{array}$ & $\begin{array}{l}-1.30 \mathrm{E}-06^{* * *} \\
(-7.7394)\end{array}$ & $\begin{array}{l}-1.01 \mathrm{E}-06^{* *} \\
(-2.2150)\end{array}$ & $\begin{array}{l}-1.73 \mathrm{E}-06 * * * \\
(-3.0274)\end{array}$ \\
\hline NLD & $\begin{array}{l}-1.34 \mathrm{E}-06 \\
(-0.4772)\end{array}$ & $\begin{array}{l}-1.33 \mathrm{E}-06 \\
(-1.486)\end{array}$ & $\begin{array}{l}-3.60 \mathrm{E}-06 \\
(-1.4505)\end{array}$ & $\begin{array}{l}-7.50 \mathrm{E}-06 * * * \\
(-4.3284)\end{array}$ & $\begin{array}{l}-2.91 \mathrm{E}-06 \\
(-0.9002)\end{array}$ \\
\hline GER & $\begin{array}{l}-2.58 \mathrm{E}-06 \\
(-1.0510)\end{array}$ & $\begin{array}{l}-9.73 \mathrm{E}-07^{* *} \\
(-2.0099)\end{array}$ & $\begin{array}{l}-3.40 \mathrm{E}-06 \\
(-1.9150)\end{array}$ & $\begin{array}{l}-2.44 \mathrm{E}-06 \\
(-1.5405)\end{array}$ & $\begin{array}{l}-5.83 \mathrm{E}-06^{* * *} \\
(-2.7802)\end{array}$ \\
\hline KOR & $\begin{array}{c}-1.37 \mathrm{E}-06 \\
(-0.2689)\end{array}$ & $\begin{array}{l}-3.50 \mathrm{E}-05^{* * *} \\
(-3.1789)\end{array}$ & $\begin{array}{l}-2.57 \mathrm{E}-05 \\
(-0.6330)\end{array}$ & $\begin{array}{l}-5.90 \mathrm{E}-07 \\
(-0.0889)\end{array}$ & $\begin{array}{c}-1.48 \mathrm{E}-05 \\
(-0.9604)\end{array}$ \\
\hline JPN & $\begin{array}{l}-4.96 \mathrm{E}-06^{*} \\
(-1.7052)\end{array}$ & $\begin{array}{l}-1.53 \mathrm{E}-06 \\
(-1.3138)\end{array}$ & $\begin{array}{l}-2.65 \mathrm{E}-06 \\
(-0.6314)\end{array}$ & $\begin{array}{l}-4.09 \mathrm{E}-06 \\
(-1.3425)\end{array}$ & $\begin{array}{l}-3.27 \mathrm{E}-06 \\
(-1.2054)\end{array}$ \\
\hline TUS & $\begin{array}{l}-5.90 \mathrm{E}-06^{* * *} \\
(-3.5149)\end{array}$ & $\begin{array}{c}-1.30 \mathrm{E}-07 \\
(-1.5684)\end{array}$ & $\begin{array}{l}-4.15 \mathrm{E}-06^{* * *} \\
(-3.2830)\end{array}$ & $\begin{array}{l}-3.98 \mathrm{E}-07 * \\
(-1.7927)\end{array}$ & $\begin{array}{l}-3.30 \mathrm{E}-07 \\
(-1.2111)\end{array}$ \\
\hline $\mathrm{KO}$ & $\begin{array}{l}-2.12 \mathrm{E}-06 * * * \\
(-7.4879)\end{array}$ & $\begin{array}{l}-8.30 \mathrm{E}-07 \\
(-1.2252)\end{array}$ & $\begin{array}{l}-1.44 \mathrm{E}-06 \\
(-0.8865)\end{array}$ & $\begin{array}{l}-2.45 \mathrm{E}-06^{* * *} \\
(-5.3442)\end{array}$ & $\begin{array}{l}-1.29 \mathrm{E}-06^{* * *} \\
(-3.7863)\end{array}$ \\
\hline MCD & $\begin{array}{l}-2.23 \mathrm{E}-06^{* * *} \\
(-7.0519)\end{array}$ & $\begin{array}{l}-3.28 \mathrm{E}-06^{* * * *} \\
(-6.9751)\end{array}$ & $\begin{array}{l}-2.00 \mathrm{E}-06^{* *} \\
(-1.9558)\end{array}$ & $\begin{array}{l}-2.60 \mathrm{E}-06^{* *} \\
(-2.3589)\end{array}$ & $\begin{array}{l}-5.46 \mathrm{E}-06 * * * \\
(-2.9376)\end{array}$ \\
\hline $\mathrm{PC}$ & $\begin{array}{l}-9.93 \mathrm{E}-05^{* *} \\
(-2.5060)\end{array}$ & $\begin{array}{l}-4.30 \mathrm{E}-05^{* * * *} \\
(-10.1986)\end{array}$ & $\begin{array}{l}-3.70 \mathrm{E}-06 \\
(-0.3402)\end{array}$ & $\begin{array}{l}-5.97 \mathrm{E}-05^{* * *} \\
(-2.6036)\end{array}$ & $\begin{array}{l}-8.46 \mathrm{E}-05 \\
(-1.3147)\end{array}$ \\
\hline VIS & $\begin{array}{l}-6.51 \mathrm{E}-05^{* * *} \\
(-7.0712)\end{array}$ & $\begin{array}{l}-2.69 \mathrm{E}-06^{* *} \\
(-2.0945)\end{array}$ & $\begin{array}{l}-9.51 \mathrm{E}-06^{*} \\
(-1.6587)\end{array}$ & $\begin{array}{l}-8.76 \mathrm{E}-06 \\
(-1.4022)\end{array}$ & $\begin{array}{l}-4.28 \mathrm{E}-06^{* * *} \\
(-7.8150)\end{array}$ \\
\hline SAM & $\begin{array}{l}3.50 \mathrm{E}-06 \\
(0.2543)\end{array}$ & $\begin{array}{l}-1.22 \mathrm{E}-08 \\
(-0.0023)\end{array}$ & $\begin{array}{l}-4.34 \mathrm{E}-06 \\
(-0.3206)\end{array}$ & $\begin{array}{l}3.14 \mathrm{E}-07 \\
(0.0160)\end{array}$ & $\begin{array}{l}-7.52 \mathrm{E}-06 \\
(-0.1626)\end{array}$ \\
\hline Firm & TGold & TMed & TSilver & TBronze & TPopular \\
\hline KO & $\begin{array}{l}-7.40 \mathrm{E}-07 \\
(-1.2302)\end{array}$ & $\begin{array}{l}-2.43 \mathrm{E}-07 \\
(-1.4399)\end{array}$ & $\begin{array}{l}7.22 \mathrm{E}-07 \\
(-1.0816)\end{array}$ & $\begin{array}{l}-6.40 \mathrm{E}-07 \\
(-0.9330)\end{array}$ & $\begin{array}{l}-5.52 \mathrm{E}-07 \\
(-0.9381)\end{array}$ \\
\hline $\mathrm{MCD}$ & $\begin{array}{l}-3.83 \mathrm{E}-06 \\
(-1.5002)\end{array}$ & $\begin{array}{l}-1.06 \mathrm{E}-06^{* * *} \\
(-2.7367)\end{array}$ & $\begin{array}{l}-3.56 \mathrm{E}-06 * * * \\
(-9.4940)\end{array}$ & $\begin{array}{l}-6.66 \mathrm{E}-07^{* * *} \\
(-2.7669)\end{array}$ & $\begin{array}{l}-7.00 \mathrm{E}-06^{* * *} \\
(-5.6443)\end{array}$ \\
\hline $\mathrm{PC}$ & $\begin{array}{l}3.15 \mathrm{E}-08 \\
(0.0381)\end{array}$ & $\begin{array}{l}1.32 \mathrm{E}-08 \\
(0.0552)\end{array}$ & $\begin{array}{l}4.35 \mathrm{E}-08 \\
(0.0526)\end{array}$ & $\begin{array}{l}4.20 \mathrm{E}-08 \\
(0.0508)\end{array}$ & $\begin{array}{l}-6.47 \mathrm{E}-06^{* * *} \\
(-17.9240)\end{array}$ \\
\hline VIS & $\begin{array}{l}-2.37 \mathrm{E}-05^{* * *} \\
(-12.19923)\end{array}$ & $\begin{array}{l}-5.25 \mathrm{E}-06^{* * *} \\
(-36.06726)\end{array}$ & $\begin{array}{l}-2.30 \mathrm{E}-06^{* *} \\
(-2.2985)\end{array}$ & $\begin{array}{l}-2.46 \mathrm{E}-06^{* * *} \\
(-2.9433)\end{array}$ & $\begin{array}{l}-7.19 \mathrm{E}-06^{* * * *} \\
(-8.0901)\end{array}$ \\
\hline SAM & $\begin{array}{l}\text { 7.72E-09 } \\
(0.0061)\end{array}$ & $\begin{array}{l}-5.10 \mathrm{E}-09 \\
(-0.0133)\end{array}$ & $\begin{array}{l}-6.42 \mathrm{E}-08 \\
(-0.0496)\end{array}$ & $\begin{array}{l}1.18 \mathrm{E}-08 \\
(0.0089)\end{array}$ & $\begin{array}{l}-9.12 \mathrm{E}-08 \\
(-0.0880)\end{array}$ \\
\hline
\end{tabular}

This table gives the value of the GJR GARCH $(1,1)$ coefficients $\delta$ in model $(5)$. Numbers in brackets correspond to z-statistic values. Heteroskedasticity and autocorrelation consistent standard errors are estimated using the Newey and West (1987) approach. ***, *** denote statistical significance at the 1\%, $5 \%$ and $10 \%$ level, respectively. When TUS is used, it is the total number of medals for all eight countries, the historical volatility corresponds to the US. When analysing firms, the number of medals and historical 
1

8

9

10

11

12

13

14

15

16

17

18

19

20

21

22

23

24

25

26

27

28

29

30

31

32

33

34

35

36

37

38

39

40

41

42

43

44

45

46

47

48

49

50

51

52

53

54

55

56

57

58

59

60 volatility correspond to the market where the firm is listed. We also use the total number of medals for the eight countries analysed in order to capture a more global effect of medals on firms which may result from international exposure. 

Table 6: Economic significance of results: VIX and S\&P 500 futures trading strategies

\begin{tabular}{llccc}
\hline & Strategy & $\begin{array}{c}\text { Daily } \\
\text { Return }\end{array}$ & Contracts & $\begin{array}{c}\text { Profitable } \\
\text { Trades }\end{array}$ \\
\hline \multirow{4}{*}{ VIX } & US Gold Medals & $1.79 \%$ & 156 & $60.98 \%$ \\
& US Popular Gold Medals & $1.48 \%$ & 106 & $60.98 \%$ \\
& Total Gold Medals & $4.28 \%$ & 483 & $62.79 \%$ \\
& Total Popular Gold Medals & $1.96 \%$ & 179 & $61.90 \%$ \\
& Buy \& Hold & $-0.09 \%$ & 4 & $50.00 \%$ \\
& Sell \& Hold & $0.09 \%$ & 4 & $50.00 \%$ \\
\cline { 2 - 5 } S\&P 500 & US Gold Medals & $-0.36 \%$ & 156 & $56.10 \%$ \\
& US Popular Gold Medals & $-0.28 \%$ & 106 & $56.10 \%$ \\
& Total Gold Medals & $-1.56 \%$ & 483 & $55.81 \%$ \\
& Total Popular Gold Medals & $-0.46 \%$ & 179 & $57.14 \%$ \\
& Buy \& Hold & $-0.01 \%$ & 4 & $50.00 \%$ \\
& Sell \& Hold & $0.01 \%$ & 4 & $50.00 \%$ \\
\hline
\end{tabular}

Trading signals are constructed on the basis of medals awarded since the previous working day.

Four different signals are considered: total number of US gold medals, total number of US gold medals in popular sports, total number of gold medals across all countries and total number of gold medals across all countries in popular sports. 
Table 7: Impact of Olympic Games on monthly sentiment indicators for U.S

\begin{tabular}{lll}
\hline Index & Sample & Coefficient \\
\hline Michigan & $1952-2012$ & 1.6042 \\
& $(0.4009)$ \\
& $1984-2012$ & -1.3057 \\
$(-0.2764)$ \\
& $\begin{array}{l}1.7240 \\
(0.2082)\end{array}$ \\
& $2000-2012$ & 0.1474 \\
& & $(0.5539)$ \\
Wurgler & $1965-2010$ & 0.2713 \\
& & $(1.1774)$ \\
& $1984-2010$ & 0.3980 \\
& & $(1.4766)$ \\
& $2000-2010$ & 0.3419 \\
& & $(0.0730)$ \\
\hline ESI & $1990-2012$ & 1.6052 \\
& & $(0.4299)$ \\
\hline PCSI & $2002-2012$ &
\end{tabular}

This table gives the value of the regression coefficients between various sentiment indicators and dummies denoting months during which Olympics take place. Numbers in brackets correspond to t-statistics. Heteroskedasticity and autocorrelation consistent standard errors are estimated using the Newey and West (1987) approach. ***, **** denote statistical significance at the 1\%, 5\% and $10 \%$ level, respectively. 

Table 8: Impact of Olympic Games and performance on the weekly AAII sentiment for U.S.

\begin{tabular}{lccccc}
\hline U.S. & Med $_{\mathrm{t}-1}$ & Gold $_{\mathrm{t}-1}$ & Silver $_{\mathrm{t}-1}$ & Bronze $_{\mathrm{t}-1}$ & Popular $_{\mathrm{t}-1}$ \\
& 0.0011 & 0.0031 & 0.0055 & -0.0025 & 0.0035 \\
& $(0.4763)$ & $(0.5023)$ & $(0.7311)$ & $(-0.4756)$ & $(0.9552)$ \\
\hline Aggregate & TMed $_{\mathrm{t}-1}$ & TGold $_{\mathrm{t}-1}$ & TSilver $_{\mathrm{t}-1}$ & TBronze $_{\mathrm{t}-1}$ & TPopular $_{\mathrm{t}-}$ \\
& 0.0005 & 0.0017 & 0.0013 & 0.0015 & 0.0022 \\
& $(0.7621)$ & $(0.9411)$ & $(0.5752)$ & $(0.6878)$ & $(1.0762)$ \\
\hline
\end{tabular}

This table gives the value of the regression coefficients between sentiment and medals won from the previous week $(\mathrm{t}-1)$. Numbers in brackets correspond to t-statistics. Heteroskedasticity and autocorrelation consistent standard errors are estimated using the Newey and West (1987) approach. ***, **,* denote statistical significance at the 1\%, 5\% and $10 \%$ level, respectively. 
Table 9: Impact of Olympic Medals over previous day on investor attention measured by Google SVI

\begin{tabular}{lllllll}
\hline Market & Gold & Med & Silver & Bronze & Popular & Surprise \\
\hline US & $-0.0652^{* *}$ & $-0.0275^{* *}$ & $-0.0585^{*}$ & $-0.0963^{* * *}$ & $-0.0377^{* * *}$ & -0.9420 \\
& $(-2.4727)$ & $(-2.3706)$ & $(-1.8138)$ & $(-2.8875)$ & $(-2.7616)$ & $(-1.2810)$ \\
UK & $-0.1590^{* * *}$ & $-0.0788^{* * *}$ & $-0.1093^{* *}$ & $-0.2067^{* * *}$ & $-0.1913^{* * *}$ & -0.1847 \\
& $(-5.1366)$ & $(-4.0962)$ & $(-2.5352)$ & $(-3.6956)$ & $(-2.2801)$ & $(-0.2157)$ \\
FRA & -0.0415 & 0.0086 & 0.0595 & 0.0053 & 0.0236 & -0.1781 \\
& $(-0.1183)$ & $(0.0709)$ & $(0.3564)$ & $(0.0239)$ & $(0.1012)$ & $(-0.0572)$ \\
AUS & $-0.1122^{* * *}$ & $-0.0615^{* * *}$ & $-0.1190^{* * *}$ & $-0.1536 * * *$ & $-0.0708^{* *}$ & $1.7402^{* *}$ \\
& $(-3.4351)$ & $(-3.3762)$ & $(-2.7703)$ & $(-3.4737)$ & $(-2.5638)$ & $(2.6691)$ \\
NLD & $-0.1023^{* * *}$ & $-0.0597 * *$ & -0.0612 & $-0.1112 * *$ & $-0.1326 * * *$ & 1.2210 \\
& $(-2.6119)$ & $(-2.4549)$ & $(-1.4822)$ & $(-1.9838)$ & $(-2.8939)$ & $(0.7937)$ \\
GER & -0.0530 & $-0.0292^{* *}$ & -0.0531 & $-0.0782^{* *}$ & -0.0390 & $-0.8908 * *$ \\
& $(-1.4282)$ & $(-1.9954)$ & $(-1.5174)$ & $(-2.0302)$ & $(-1.1295)$ & $(-2.5325)$ \\
JPN & -0.0514 & -0.0730 & $-0.2293 *$ & -0.1333 & -0.0936 & 0.7331 \\
& $(-0.4962)$ & $(-1.0739)$ & $(-1.8560)$ & $(-1.1939)$ & $(-0.8704)$ & $(0.3351)$ \\
\hline
\end{tabular}

Numbers in brackets correspond to t-statistics. Heteroskedasticity and autocorrelation consistent standard errors are estimated using the Newey and West (1987) approach. ***,**,* denote statistical significance at the 1\%,5\% and $10 \%$ level respectively. 